\title{
Antibiotic Induced Rash in Infectious Mononucleosis
}

\section{Enfeksiyöz Mononükleozda Antibiyotiğe Bağlı Döküntü}

\author{
Ergin Çiftçi'(iD), Esra Çakmak Taşkın'(iD), Gül Arga'(iD), Hatice Kübra Konca'(i D), Halil Özdemir'1(iD) \\ ${ }^{1}$ Division of Pediatric Infectious Diseases, Department of Pediatrics, Ankara University School of Medicine, Ankara, Turkey
}

Cite this article as: Çiftçi E, Çakmak Taşkın E, Arga G, Konca HK, Özdemir H. Antibiotic induced rash in infectious mononucleosis. J Pediatr Inf 2021;15(1):e62.

A two-year-old male patient was brought with the complaint of rash. It was learned that he had been to the hospital with the complaints of fever and dysphagia a week ago, and amoxicillin-clavulonate was started with the diagnosis of throat infection. It was stated that he had a fever during this treatment and started snoring at night. The patient's rash had started in the abdomen the day before and spread all over his body. In the physical examination of the patient, his tonsils were hypertrophic and cryptic, he had extensive lymphadenopathies, the largest of which was $2 \mathrm{~cm}$ in diameter in the anterior cervical region, and inspiratory stridor. The liver and spleen were $3 \mathrm{~cm}$ palpable below the costal margins. He had a widespread maculopapular rash that faded with pressure throughout the body, more prominent on the trunk and face. Leukocyte: $10.000 / \mathrm{mm}^{3}$ (lymphomonocytosis in peripheral smear, 27\% Downey cells), hemoglobin: $12.8 \mathrm{~g} / \mathrm{dL}$, platelets: 269,000/mm³ , ALT: $135 \mathrm{U} / \mathrm{L}$, AST: $107 \mathrm{U} / \mathrm{L}$ were detected in his laboratory tests. Epstein-Barr virus (EBV) induced infectious mononucleosis and antibiotic rash were considered. Antibiotic treatment was discontinued, prednisolone $1 \mathrm{mg} / \mathrm{kg}$ was given for 2 days due to respiratory distress. EBV VCA IgM and IgG were positive. In the follow-up, the patient's rash, hepatosplenomegaly, and lymphadenopathies regressed, and liver enzymes returned to normal.

EBV typically presents with fever, exudative pharyngitis, lymphadenopathy, and hepatosplenomegaly. The presence of more than $10 \%$ atypical lymphocytes in peripheral smear supports the diagnosis. Diagnosis is confirmed by demon- strating antibodies against viral antigens. Although infectious mononucleosis usually resolves spontaneously, if there is respiratory obstruction due to enlarged lymph nodes, steroids can be used in the treatment. Rash may occur in patients treated with ampicillin or amoxicillin. The use of ampicillin or amoxicillin should be avoided in patients with suspected infectious mononucleosis, as they may cause a rash.

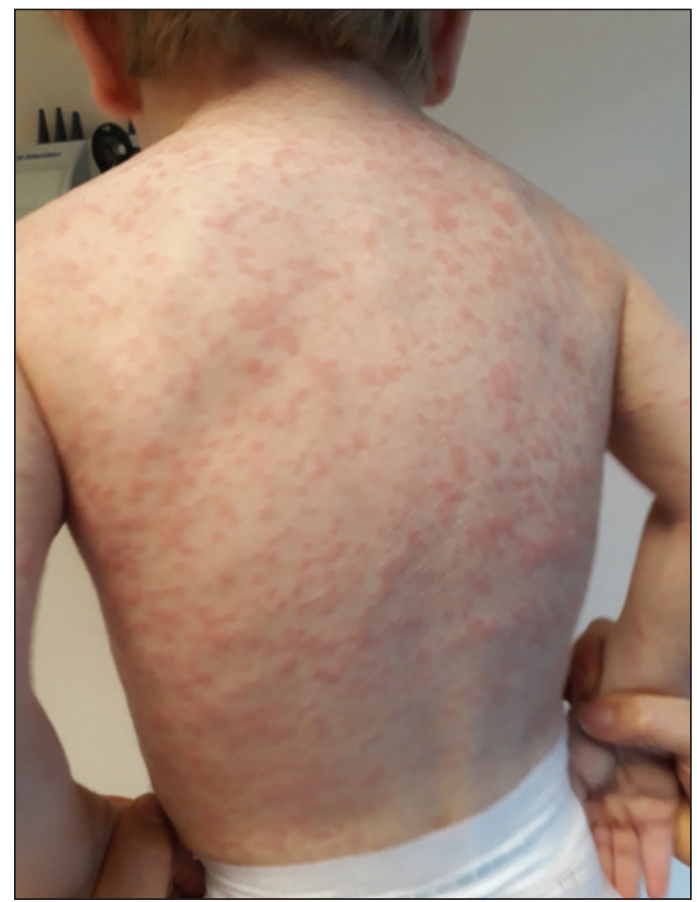

Correspondence Address/Yazışma Adresi

Ergin Çiftçi

Ankara Üniversitesi Tıp Fakültesi,

Cocuk Sağlığı ve Hastalıkları Anabilim Dalı,

Çocuk Enfeksiyon Hastalıkları Bilim Dalı,

Ankara-Türkiye

E-mail: erginciftci@gmail.com 